\title{
Reading Test-Sentence Comprehension: An Adapted Version of Lobrot's Lecture 3 Test for Brazilian Portuguese
}

\author{
Douglas de Araújo Vilhena', Ana Sucena ${ }^{2}$, São Luís Castro ${ }^{3}$ and \\ Ângela Maria Vieira Pinheiro ${ }^{1 *}$ \\ 'Department of Psychology, Universidade Federal de Minas Gerais, Brazil \\ ${ }^{2}$ School of Allied Health Sciences, Instituto Polité cnico do Porto, Portugal \\ ${ }^{3}$ Faculty of Psychology and Educational Sciences, Universidade do Porto, Portugal
}

\begin{abstract}
Our aim was to analyse the linguistic structure of the Lobrot's Lecture 3 (L3) reading test and to describe the procedure for its adaptation to a Brazilian cultural-linguistic context. The resulting adapted version is called the Reading Test-Sentence Comprehension [Teste de Leitura: Compreensão de Sentenças (TELCS)] and was developed using the European Portuguese adaptation of $\mathrm{L} 3$ as a reference. The present study was conducted in seven steps:

(I) classification of the response alternatives of $L 3$ test; (2) adaptation of the original sentences into Brazilian Portuguese; (3) back-translation; (4) adaptation of the distractors from TELCS; (5) configuration of TELCS; (6) pilot study; and (7) validation and standardization. In comparison with L3, TELCS included new linguistic and structural variables, such as frequency of occurrence of the distractors, gender neutrality and position of the target words. The instrument can be used for a collective screening or individual clinical administration purposes to evaluate the reading ability of second-to-ffth-grade and 7-to-I I-year-old students.
\end{abstract}

Keywords: reading assessment; specific learning disabilities; Teste de Idade de Leitura; reading diagnosis; silent reading

The evaluation of reading ability is fundamental for early intervention in children who struggle with learning at school. Such evaluation is especially relevant in Brazil because of the low scores on national and international scholastic assessments achieved by our population. Only $56 \%$ of 8 -year-old children are fully literate (Todos pela Educação, 20I3), with II\% of people from I 5 to 24 years old unable to understand or produce the texts they need despite having attended school (Instituto Paulo Montenegro, 20I I). Internationally, for instance, according to the Programme for International Student Assessment (Organisation for Economic Co-operation and Development, 2013), Brazil was among the worst countries for reading (ranking 55 out of 65 ).

\footnotetext{
*Correspondence to: Ângela Maria Vieira Pinheiro, Department of Psychology, Universidade Federal de Minas Gerais, Av. Antônio Carlos, 6627, Pampulha 31270-90I, Belo Horizonte, Minas Gerais, Brazil. E-mail: pinheiroamva@gmail.com
} 
These disappointing results are not due to limited opportunities for attending school but rather to the ineffective instructional strategies in schools and poor socio-economic background, especially within the public educational system (Duncan \& Seymour, 2000; Soares, 2004). Children under such circumstances are at permanent risk of reading failure and need to have their learning screened frequently.

Thus, the construction or adaptation, and subsequent validation, of instruments designed to allow early identification of reading problems has become an important investment. In this context, the current work aims to adapt the Lecture 3 (L3) test of the ORLEC battery, which is an instrument that measures basic reading skills (word recognition and understanding), to the Brazilian context. This tool is widely used in both educational and research contexts of francophone countries and in Portugal.

\section{Lecture 3 Test of the ORLEC Battery}

Originally constructed in French, the ORLEC battery was proposed by Lobrot (1967, 1980) to evaluate the writing (OR-orthographe) and reading (LEC-lecture) efficiency of children from 7 to 13 years old. The reading portion of the battery is divided into four tests as follows: (I) Lecture I: reading a short text aloud; (2) Lecture 2: silent reading of isolated words followed by a semantic association judgement; (3) Lecture 3: silent reading of incomplete sentences; and (4) Lecture 4: silent reading of a long text followed by questions.

Lecture 3 is a reliable screening of students' reading ability and can be administered quickly to groups of pupils or individually. It consists of 40 items of increasing difficulty, formed by a sequence of single incomplete sentences, each followed by a choice of five words as alternative completions. Among these alternatives, only one can correctly complete the sentence. The remaining alternatives are distractor stimuli that share phonological, orthographic or semantic similarity with the target word (Piérart \& Grégoire, 2004; Reybroeck \& Hupet, 2009).

The child's task is to select the word that is meaningful within the sentence. First, there are four training items that are used to demonstrate how the task should be performed (at this stage, the correct response is explicitly indicated to the child). The other 36 sentences are then completed individually and in silence within a 5min time limit, without any help from the instructor. The test assesses the relationship between performance and speed because the result corresponds to the number of items correctly answered in $5 \mathrm{~min}$.

According to the author of the $L 3$ and of all subsequent studies about it, the test measures both the decoding and semantic components of reading. As for 'decoding', we agree that the test taps this ability but only to 7-8years typical developing children and those with specific reading difficulties. As the L3 is aimed to children aged between 7 and I 3 years, to also capture the reading process of the older children, we argue for the addition of the term 'lexical word recognition' among the reading abilities measured by L3 and its adaptations. This is necessary because in order to grasp the meaning of sentences rapidly and efficiently, the reader must have already passed the decoding phase. In this early phase of learning to read, meaning is accessed indirectly via phonological mediation. The child, being engaged in the effortful and time consuming grapheme-phoneme conversion process (decoding) mode of recognizing words, is left with few resources to direct to the accessing of the meaning of the words. In 
addition, L3 requires the choice of a target word among distractors, which also demands working memory. Therefore, successful performance in the test requires quick lexical recognition of words.

The L3 addresses the age range of children by introducing increasingly more complex items. The present adaptation, in addition to this control and focusing on the reading ability covered by the test (from decoding to lexical word recognition), was envisaged in a way that the items at the beginning of it are composed of high frequency regular words. As they can be easily decodable, the sentence comprehension is thus facilitated. Studies are needed to measure how many items a child in the decoding phase can answer. As for the Teste de Leitura: Compreensão de Sentenças (TELCS), the Brazilian adaptation of the L3 and the object of the present article, what we know at the moment is that the norms published in Vilhena and Pinheiro (20I5) reveal a floor effect in the second grade, demonstrating that a proportion of the Brazilian students are not yet reading with the expected fluency. This, which is in agreement with Salles and Parente (2002) who found that half of the second grade Brazilian pupils still majorly read via phonological mediation, shows that the TELCS can distinguish children at risk of developing a reading disorder from those with typical reading skills.

Although the L3 is almost 50 years old, the measure is of interest due to its design, ease of administration and psychometric properties. In regard to the latter, in studies with Belgium monolingual French-speaking elementary school children, while Mousty and Leybaert (1999) demonstrated the good sensitivity of the instrument for second and fourth graders (no floor or ceiling effects were encountered), Piérart and Grégoire (2004), with a sample of 2989 children (third to sixth graders), provided new norms for L3 and demonstrated its high consistency (Cronbach's alpha $=.94$, Spearman-Brown split-half coefficient $=.98$ ).

The $\mathrm{L} 3$ test has been the basis for the construction of other tests, such as the Collective Test of Reading Efficacy in Spain and the Reading Age Test in Portugal, which we will review in the following section for structural comparison purposes.

\section{Collective Test of Reading Efficacy-European Spanish}

The Collective Test of Reading Efficacy (Test Colectivo de Eficacia Lectora-TECLE) (Carrillo \& Marín, 2009; Marín \& Carrillo, 1999) has been used since 1997 for screening purposes to detect Castilian-speaking students with delayed reading. This test is part of the DIS-ESP5 battery (Carrillo \& Alegría, 2009; Luque et al., 2012).

Similar to the L3, TECLE is conducted in $5 \mathrm{~min}$ and evaluates the child's ability to manipulate information that has increasing syntactic, semantic and orthographic complexity. Another similarity between the tests is the type of distractors, which can have phonological, orthographic and semantic functions. Despite these similarities, the TECLE has some important differences from the $L 3$, such as a larger number of incomplete sentences $(N=64)$, fewer alternative choices $(N=4)$ and the presence of at least one pseudoword as a distractor for each item. These differences make the TECLE a completely new test, preventing the structural comparison of its results with those of the L3 or the present work.

\section{Reading Age Test (Teste de Idade de Leitura)—European Portuguese}

The European Portuguese adaptation of Lobrot's L3 test, the Reading Age Test [Teste de Idade de Leitura (TIL)] (Sucena \& Castro, 20I0), was undertaken in 2004. At the 
time, there were no instruments with normative data in Portugal designed to assess reading age or to screen for reading difficulties. The $L 3$ test was chosen for three main reasons: (I) it was a thoroughly tested instrument, widely adopted by both researchers and clinicians in French-speaking countries; (2) its language shares with Portuguese the same Romance origin, thus allowing for a more straightforward translation/adaptation process; and (3) it assesses reading speed and reading comprehension.

A detailed analysis of the L3 test was conducted with special attention to the types of distractors-visual, phonological, semantic or no proximity to target words. Then, the test was translated and adapted to European Portuguese, maintaining whenever possible the same type of distractor and the same average length (in number of words). As in the original Lobrot test, the sentences were made to have an increasing number of words throughout the test. Finally, the last step consisted of a validation study where the TIL was administered to $6 / 4$ children and norms for second-to-fifth grades were gathered.

Currently, the TIL is published in Portugal by Almedina. It has been adopted by the scientific and educational communities as an instrument to assess reading age in children from 8 to I l years old. Recently, initial studies have been conducted to enable the use of the TIL with the adult population, specifically to assess reading skills (Sucena, Carneiro, \& Almeida, 2014) and to screen for dyslexia in college students (the I-min TIL; Fernandes et al., 20I4). As this instrument has the same structure as the L3, it was also taken as reference in our adapted version.

The present study had two main purposes. The first was to analyse the linguistic structure of the L3 test, and the second, to describe the procedure for its adaptation to a Brazilian cultural-linguistic context, which generated the TELCS. With this work, we expect to offer guidance to those wishing to do equivalent adaptation to their own cultural-linguistic context and also to allow comparisons between the L3 and its existing versions: the Portuguese and Brazilian versions.

\section{METHODS}

The present work took into account the International Test Commission Guidelines for Translating and Adapting Tests (ITC, 2005) and the guidelines proposed by Gudmundsson (2009), as they are comprehensive works in this field and because they focus on the various conditions necessary to increase the likelihood of test equivalence. The following steps were taken in the present adaptation process: (I) classification of the response alternatives of the L3 test; (2) adaptation of the original test (sentences and target words) into Brazilian Portuguese; (3) back-translation (from Brazilian Portuguese to French); (4) adaptation of the distractors for the TELCS; (5) configuration of the Brazilian version; (6) pilot study; and (7) validation and standardization of the final instrument.

\section{Step I. Classification of the L3 Test}

This stage consisted of the analysis of the structure of the L3 to uncover the logical patterns of the sentences and response alternatives, as Lobrot did not explicitly indicate how the selection of the test elements was carried out. Both Piérart and Grégoire (2004) and Sucena and Castro (2010) indicated that the selection of the distractors 
is based on their proximity/distance to the target word or to the sentence in what concerns visual, phonological or semantic similarities. In the present study, we realized that this similarity could also be between distractors. There were also a few situations in which no resemblance to any stimuli was found. Following these rationales, the classification of the distractors was carried out by two independent psychologists, proficient in both idioms and knowledgeable about the test content. The two classifications were compared, generating a single consensual version.

For the criteria determining visual proximity, it was possible to infer that the alternatives must have an equivalent number of letters, be orthographically similar (e.g., the presence of digraphs) and have a minimum of three letters in common, regardless of order. For example, in the first item of the test (see Appendix I), it is possible to note the visual similarity between the target word (oranges) and the distractors (ordures, ombres or ordres). All of them have at least four letters in common, are of similar length and have the same ending ('es'), although none of them have strong phonological similarity.

The second distinction is phonological proximity, that occurs when there is similarity between the phonological units of the words. It can be expressed in the form of alliteration or rhyme; for example, training item 4 illustrates rhyme: accordeur, chanteur and conducteur. However, we should note that there is also a visual similarity between these words.

The third distinction is semantic proximity, which refers to the process of sharing similar semantic frameworks. In training item 4, the meaning of the word mécanicien (mechanic) is close in meaning to véhicule (vehicle). Another example can be seen in item 24, where the distractors are all names of fish species [carpe (carp), tanche (tench), truite (trout) and perche (perch)].

Finally, as mentioned, there are few distractors with no resemblance to any stimuli (word target, sentence or distractors). For example, in training item I, the distractor loin, despite being a short word, has no visual, phonological or semantic proximity with the target word lit or with the other distractors (bout, loup and jour). It is important to highlight that although the distractor bout has no similarity with the target word, it is phonologically close to the distractors 'loup' and 'jour'.

\section{Step 2. Translation into Brazilian Portuguese}

Translation of the sentences and target words from French to Brazilian Portuguese was carried by the same professionals as in Step I, as they were familiar with the culture of both languages. A conceptual translation, rather than the strictly literary one, was emphasized, taking into account the Brazilian cultural-linguistic context. To reduce discrepancies and for comparison purposes, the Brazilian version also took into consideration the European Portuguese adaptation (TIL). The translated versions were compared, generating a single consensual version.

\section{Step 3. Back-Translation}

A blind back-translation procedure was performed, where the translators- $\mathrm{a}$ Brazilian French teacher (also a psychologist) and a native French speaker, highly proficient in Portuguese - had no access to the L3 and worked independently. The two French 
versions produced were compared both to each other and to the original version (L3), and the very few discrepancies were then corrected in the Portuguese text.

\section{Step 4. Adaptation of the Distractors}

In this step, the distractors (incorrect alternatives) were selected for the 40 items. The alternatives followed the same classification pattern as the original Lobrot test as described in Step I (see Results section). The exception was that the variable 'frequency of occurrence of words', according to the Word Frequency Count in Written Brazilian Portuguese (Pinheiro, 1996, 2015), was included in the selection of the distractors. The purpose of this control is to prevent the activation of a given alternative to guide the response because of its greater familiarity to the reader.

As Pinheiro's word count has a specific list of frequency of occurrence for each school grade, it was possible to divide the test into four parts, corresponding to an estimated amount of items correctly answered by an average child in each grade: second grade (training items until item 9); third grade (items 10 to 18); fourth grade (items 19 to 27); and fifth grade (items 28 to 36). For each grade, it was also possible to match the level of frequency of occurrence (high, medium or low) between the target word and distractors. For example, in the first sentence of the test for second grade, the target word 'laranja (orange)' is a high frequency word, which led to the choice of all distractors being this level of frequency. Another example is item I4, where the target word 'médico (doctor)' is a medium frequency word for the third grade. Following the same logic, its distractors were selected from the same level of frequency [jacaré (alligator), ninho (nest), senhor (sir) and comércio (market)]. Such classification means that in regard to the frequency variable, all alternatives may represent the same level of challenge for children in each school grade. This control was not carried out in either the L3 test or the TIL.

\section{Step 5. Configuration of the Brazilian Version}

At this stage, as in the L3 and TIL, the items were rearranged according to difficulty level. This classification took into account the length of the sentence and of the response alternatives, the configuration of the distractors, the original position in the test sequence and the syntactic complexity. Another variable controlled for was the position of the target words.

\section{Step 6. Pilot Study}

A pilot study was conducted to identify flaws and to improve the items. All participants provided informed consent, and the Ethical Committee from the Federal University of Minas Gerais approved the pilot and validation study (Certificate of Appreciation Presentation to Ethics: 177545|4.6.0000.5|49). The TELCS was administered to fifth grade students $(n=43)$ from a state school in Belo Horizonte, Brazil. Quantitative and qualitative data were analysed. For the latter, special attention was given to the comments of the students during the test. 


\section{Step 7. Validation and Standardization}

Vilhena and Pinheiro (2015) meticulously explored this validation step and provided standardization and a cross-cultural comparison between the TELCS and both the Belgium (Piérart \& Grégoire, 2004) and Portuguese (Sucena \& Castro, $2010)$ norms. All the procedures and results related to this validation procedure are summarized in the following sections.

A sample of 484 students from the second to fifth grade of eight state schools in Belo Horizonte were tested with the following measures: (I) Reading Comprehension subtest (Capellini, Oliveira \& Cuetos, 20 I2); (2) Raven's Coloured Progressive Matrices Test (Angelini, Alves, Custodio, Duarte, \& Duarte, 1999); (3) Strengths \& Difficulties Questionnaire (Goodman, 1997); and (4 and 5) Word Reading Task (WRT) and the Pseudoword Reading Task (PWRT) (Cogo-Moreira, Ploubidis, De Avila, Mari, \& Pinheiro, 20I2; Pinheiro, 20I3).

Regarding the scoring of the TELCS, correct items counted one point and incorrect or blank items 0 points. As the TELCS evaluates the reading competence as a whole, a dimension reduction by principal component analysis (Carreira-Perpiñán, 1997) was used to incorporate three reading measures (PROLEC and accuracy rate of the WRT and PWRT) to create a robust reading variable, the general reading composite.

\section{Instruction for a Collective Administration of the TELCS}

'Dear participants. We are now going to play a game in which you have to complete sentences very quickly. Because of this, please only use a pen or a pencil and not an eraser. Do not turn the sheets I am handing out to you until you are told to do so. Let's

Table I. L3, TIL and TELCS-frequencies of (I) distractor type; (2) number of words and letters in the test; and (3) position of the target word in the response alternatives

\begin{tabular}{llccc}
\hline Category & & L3 & TIL & TELCS \\
\hline Phonological proximity & to the target & 49 & & 49 \\
Visual proximity & to the distractors & 9 & & 9 \\
& to the sentence & 1 & & 52 \\
& to the target & 46 & & 12 \\
Semantic proximity & to the distractors & 12 & & 32 \\
No proximity & to the sentence & 37 & & 7 \\
to the target & 7 & 33 & & 1 \\
Homophone & to the target & 1 & 582 & 0 \\
\hline Number of words in the test & to the distractors & 1 & 3118 & 3285 \\
Number of letters in the test & to the target & 655 & 4 & 8 \\
\hline Target position & & 3598 & 12 & 8 \\
& A & 5 & 7 & 8 \\
& $\mathrm{~B}$ & 11 & 7 & 8 \\
\hline
\end{tabular}


Table 2. Similarity between sentences in the French (L3), the Portuguese (TIL) and the Brazilian (TELCS) tests

\begin{tabular}{cccc}
\hline & L3 with TIL & L3 with TELCS & TELCS with TIL \\
\hline Unaltered & 22 & 26 & 25 \\
Slight change & 10 & 8 & 9 \\
Moderate change & 5 & 5 & 4 \\
Radical change & 3 & 1 & 2 \\
\hline
\end{tabular}

do the first page together. You can see four incomplete sentences each followed by five alternatives. You must select the best word to give meaning to the sentences. Now follow me in silence while I read the first training item aloud (in order not to give away the target word, all alternatives are read with the same intonation). So, which is the best word to complete the sentence? (after the students respond, the correct answer is confirmed). Mark the correct answer with an ' $X$ '. Now read in silence items 2 to 4 and I will check if you are playing correctly. Now you will have 5 minutes to answer as many items as you can on the second page, like you have just done. During the game, you will not be able to ask any questions. If you do not know an item, just skip it. Now, please start. (allow only 5 minutes of test). Ok, the game is over. Please put down your pen or pencil. Do not worry if you could not answer all the questions.'

\section{RESULTS}

\section{Step I. Classification of the L3 Test}

As seen in Table I, phonological proximity $(n=49)$ and visual $(n=46)$ proximity in relation to the target word were the most frequent distractor types in the L3 test. Semantic proximity in relation to the sentence occurred 37 times, representing $23 \%$ of the distractors. In addition, it contains only one occurrence of a homophone (the target word 'mer' and the distractor 'mère'). Another unique occurrence is the visual proximity to one of the words in the sentence, such as the distractor 'chaîne' and the key word of the sentence 'chien'.

\section{Step 2. Adaptation of the L3 into Brazilian Portuguese}

Table 2 shows the comparisons between the L3 and TELCS, between the L3 and TIL, and finally between the TELCS and TIL. Because of peculiarities of the different languages, any translation of materials from one language to another involves adaptations that can demand minor to major alterations. As shown, the meaning of the majority of the items of the L3 was kept in both the Brazilian and the Portuguese adaptations, with the TELCS showing a closer proximity to the L3 than the TIL. For the remaining items, the departure from the ideal of preserving the same meaning as the original version was due to (I) ethical reasons (e.g., items with violent content), (2) the search for precision and (3) the necessity of contextual adjustment. As a result, some of the items of the $L 3$ underwent changes that were slight (only a few words were modified, but the general meaning of the sentence was kept), moderate (the semantic context of the sentence was modified, but its syntactic structure was maintained) or radical (alteration in semantics and syntax). 
For the comparison between the L3 and TELCS, the items in the Brazilian adaptation that underwent a slight change were numbers $2,10,12,16,22,23,24$ and 33 . In the case of items 2 and 10 , for ethical reasons, the negative nature of the sentences was minimized. For example, in item 10, the negative intensity of the sentence 'There was a big accident: the train got of the rails' (II y a eu un grand accident: la locomotive est sortie des rails) was altered to 'People got frightened: the train got of the rails.'

In the remaining items, item 22 ('Everyone went by car to the forest and then we sat on the grass, where we ate our meals') illustrates a modification made to make the item more precise [e.g., the word 'forest' (forêt) was translated as 'park', as people normally sit in the grass in a park], while item 23 ('They are going to the races on Sunday because they like to see the horses running on the track') includes a contextual change: 'horse running' to 'car race', as horseracing is not part of the reality of Brazilian children.

For the items that required moderate changes in their structure, the alterations were performed for ethical reasons (items 8,13 and 21 ) or in an attempt to adapt the items to the Brazilian context (items I3, 29 and 30). Item I 3 ['II est parti à la chasse, c'est pourquoi il a pris son fusil' (He went out to hunt, and that is why he took his)] exemplifies both situations well, as the use of firearms, apart from being illegal in Brazil, has a violent connotation. Additionally, hunting animals is not a sport in our country. Therefore, this item was changed into 'She went out in a hurry, so she forgot her purse.'

Finally, radical changes were necessary only for item 32 . The original sentence was not only unclear but hard to adapt to Portuguese. The European Portuguese adaptation of this sentence also suffered a radical change that was used in the Brazilian adaptation.

Another variable controlled in the present adaptation of the L3 was gender. Many sentences in the original version, when translated into Portuguese, could be either in the masculine or feminine forms, rather than applicable to both genders. This is the case of the sentence 'je suis fatigué' (I am tired), in which 'tired' can be, in Portuguese, 'cansado' (masculine) or 'cansada' (feminine). Items with a determined gender can be ambiguous when presented to the opposite gender and that this ambiguity can lead to a delay in the response. Thus, in the TELCS, special care was taken to always use neutral sentences such as 'estou com sono' (I'm sleepy) applicable to either gender.

In the comparison between the TELCS and TIL, 25 items have the same semantic meaning and 9 items are slightly different, as seen in Table 2. Only six items were moderately to radically divergent. As such, the $\mathrm{L} 3$ and TIL demonstrate approximately the same difference from the Brazilian adaptation. In other words, the three versions are comparable.

\section{Step 3. Adaptation of the Distractors}

As seen in Table I, there were only a few differences between the L3 and TELCS. The alternatives that differed from the original version were due to the inability to find a matching word in the Brazilian Word Frequency Count list. For example, in item 4, the target word mer (sea) and the distractor mère (mother) are homophones. Because of the lack of a Portuguese homophone for 'mar' (sea), the chosen translation for the distractor was 'par' (pair), which has phonological and visual proximity. 
Considering the variable frequency of occurrence of words classification, the Brazilian adaptation has 6 items (15\%) with high frequency, 6 (15\%) with medium frequency and $28(70 \%)$ with low frequency.

\section{Step 4. Back-Translation}

First, only the items that maintained the same semantic meaning in the Translation into the Brazilian Portuguese step were compared $(n=26)$. After the semantic comparison of the two back-translations with the original French test, it was found that all the items had the same original meaning; thus, they did not require any adjustments. Later, the items that suffered a slight change were compared $(n=8)$. When one takes into account how few words were modified in the adaptation of these items, the back-translation of each of them corresponded well to the original item.

The TELCS has 32 target words (80\%) with the same meaning as the original L3 test. This identity of meaning between the versions was confirmed in the backtranslation. This means that only eight target words $(20 \%)$ had to be modified because of the change in the composition of the sentence or to adapt to the Brazilian sociocultural context [e.g., jonquilles (daffodils) was translated to 'roses'].

\section{Step 5. Configuration of the Brazilian Version}

The original structure of the test was preserved: four training items on the front page, each item occupying up to two lines, followed by the test items that were arranged according to a gradual increase in difficulty level. As already mentioned, one of the criteria for the difficulty ranking was the length of each item (number of words and letters in the sentence plus the alternatives). As seen in Table I, the TELCS has fewer words $(-9 \%)$ and letters $(-9 \%)$ (the equivalent to 3.6 items) than $\mathrm{L} 3$, but more words $(2 \%)$ and letters $(5 \%)$ (the equivalent to two items) than TIL. The comparison between TIL and L3 shows that the Portuguese test has fewer words $(-11 \%)$ and letters $(-13 \%)$ than the French one (equivalent to 4.8 items). Thus, considering that the quantity of information (measured by the item length) matters in time measured instruments, the L3 is the hardest test, followed by the TELCS, with the TIL being the easiest.

Table I shows that there was a large discrepancy between the targets' positions in the original test and in the TELCS, with the target words being twice as likely to be in the second position (B) than in the first position (A). This discrepancy is even larger in the TIL, where the target word is three times more frequently in position $B$ than in position $A$. In the Brazilian version, the positions of all target words are equally distributed ( $20 \%$ occurrence in each position). Moreover, because the alternatives set to high and medium frequencies of occurrence are more easily answered than the low frequency of occurrence alternatives because of the familiarity effect, they were not allocated to position A or B.

\section{Step 6. Pilot Study}

The scores of the TELCS (Male: range $=20$ to $34, M=27, S D=4.6$; Female: range $=24$ to $36, M=3 \mathrm{I}, \mathrm{SD}=4.3$ ) were in agreement with Piérart and Grégoire's (2004) norms, as well as with Sucena and Castro's (2010). The very high Cronbach's alpha (.92) demonstrated very good reliability of the items. The 
qualitative analyses conducted consisted of the identification and correction of flaws and dubious distractors.

\section{Step 7. Validation and Standardization}

The validation and standardization of the TELCS are described in Vilhena and Pinheiro (20I5). In the referred study, the TELCS showed a very good internal validity, demonstrated by a schooling effect (second $<$ third $<$ fourth $<$ fifth grade), age effect $(7<8<9<10<$ II years old) and the high Cronbach's alpha (.967). Good concurrent validation was demonstrated by the moderate-to-strong correlation with all of the reading measures, such as accuracy rate of Word and Pseudoword Reading Tasks ( $r=.840$ and .787$)$ and with the general reading composite $(r=.837)$. The standardization study demonstrated that the large number of items in the test $(N=36)$ enabled the clear differentiation and classification of the reading performance of students, which was divided by five proficiency groups (reading disability, low performance, average performance, above average performance and high performance).

\section{DISCUSSION}

The objective of this study was to describe the construction procedure of the Reading Test-Sentence Comprehension (TELCS) developed by adapting Lobrot's L3 reading test to a Brazilian cultural-linguistic context. The $L 3$ was chosen because it is an important francophone instrument to evaluate the reading ability of young students. Because of its high consistency, good reliability and updated norms, it has been the basis of developing equivalent tests both in Spain and in Portugal.

The TELCS, as with its predecessors, is a decision-making test that measures the reading accuracy (word recognition), speed, vocabulary knowledge and comprehension of written materials. In comparison with the L3, the TELCS included new linguistic and structural variables, such as frequency of occurrence of the distractors, gender neutrality and position of the target word.

The instrument has been submitted to a validation and standardization process, and the results of that study, reported in Vilhena and Pinheiro (2015), demonstrated a robust schooling and age effects and significant correlations with all tests used to measure reading and general cognitive ability. Additionally, it is a good measure to evaluate a child's academic year (second to ffth grade) and reading age (7 to II years). The data reveal that the instrument is reliable to access the reading ability of students ranging from weak to high global performance up to the fourth grade. The ceiling effect found in the fifth grade shows that the TELCS presents limitations in discriminating the reading performance of students at advanced levels of schooling.

\section{CONCLUSION}

Because of the rigorous procedure of its adaptation to the Brazilian context and the extra control of variables introduced as well as the good results of the validation study, the TELCS has proven to be a reliable instrument for evaluating the global reading competence of students from second to fifth grade (7-I I years old) and is a good estimator of school grade and chronological age. Because the TELCS has 
many linguistics components embedded in its structure, it allows for the screening of different cognitive functions in a single assessment. Additionally, this instrument, as its predecessors, can be used for a collective screening or for individual clinical administration purposes to evaluate a child's reading grade. The appendix of this paper is an important tool to use for future adaptations of the $L 3$ to other languages as well as for the construction of new tests.

\section{ACKNOWLEDGEMENTS}

This work was supported by the Pró-Reitoria de Pesquisa da Universidade Federal de Minas Gerais and Conselho Nacional de Desenvolvimento Científico e Tecnológico (CNPq, grant no. 134357/20 I3-2). These bodies had no involvement in the study design; collection, analysis and interpretation of data; writing of the report; or the decision to submit the article for publication. The adaptation of TELCS was developed as part of D. A. V.'s Master Thesis, under the supervision of A. M. V.P.

\section{CONFLICT OF INTEREST}

The authors declare no conflicts of interest.

\section{REFERENCES}

Angelini, A. L., Alves, I. C. B., Custódio, E. M., Duarte, W. F. \& Duarte, J. L. M. (I 999). Matrizes Progressivas Coloridas de Raven: Escala Especial [Raven's Coloured Progressive Matrices: Special Scale]. São Paulo: CETEPP.

Carrillo, M. S., \& Alegría, J. (2009). Exploración de habilidades fonológicas en escolares disléxicos: teoría y práctica. Revista de Logopedia, Foniatría y Audioloǵla, 29, I05-120. doi:I0.1016/S02 I4-4603(09)70I49-4.

Carrillo, M.S., \& Marín, J. (2009). Test de Eficiencia Lectora-TECLE. In A. Cuadro, D. Costa, D. Trias \& P. Ponce de León (Eds.), Evaluación del nivel lector: manual técnico del test de eficacia lectora (TECLE). Uruguay: Prensa Médica Latinoamericana. ISBN: 978-9974-5684-2-6

Cogo-Moreira, H., Ploubidis, G., De Avila, C., Mari, J. \& Pinheiro, A. M. V. (20I2). EACOL (scale of evaluation of reading competency by the teacher): Evidence of concurrent and discriminant validity. Neuropsychiatric Diseases and Treatment 8, 443-454.

Capellini, S. A., Oliveira, A. M. \& Cuetos, F. (2012). PROLEC: Provas de Avaliação dos Processos de Leitura (2nd ed.). São Paulo: Casa do Psicólogo.

Duncan, L. G., \& Seymour, P. H. K. (2000). Socio-economic differences in foundation level literacy. British Journal of Psychology, 9I, I45-166.

Fernandes, T., Araújo, S., Sucena, A., Reis, A., \& Castro, S.L. (2014). Reading skills in young adults: Psychometric properties of a screening test of reading in Portuguese college students. Manuscript submitted for publication.

Goodman, R. (1997). The Strengths and Difficulties Questionnaire: a research note. Journal of Child Psychology and Psychiatry 38, 58I-586.

Gudmundsson, E. (2009). Guidelines for translating and adapting psychological instruments. Nordic Psychology, 6I(2), 29-45.

International Test Commission (2005). International Test Commission Guidelines for Translating and Adapting Tests. Final version. Retrieved May 20, 20I3, from http://www.intestcom.org/upload/ sitefiles/40.pdf [4 February 20I3]. 
Instituto Paulo Montenegro (20II). INAF Brasil 20II, Indicador de Alfabetismo Funcional. Principais resultados. Retrieved 17 November 2014 http://www.ipm.org.br [10 March 2014].

Lobrot, M. (1967). Batterie pour mesurer la lecture et l'orthographe, ORLEC. Beaumont/Oise: Bureau d'études et de recherches.

Lobrot, M. (1980). Lire avec épreuves pour évaluer la capacité de lecture (D-OR-LEC). Paris: Editions ESF.

Luque, J. L., Carrillo, M., Alegría, J., Bordoy, S., \& López-Zamora, M. (20I2). Ventajas del diagnóstico etiológico de la dislexia evolutiva: Informe automatizado a partir de la batería DIS-ESP. In J. Navarro, M. T. Fernández, F. J. Soto, \& F. Tortosa (Eds.), Respuestas flexibles en contextos educativos diversos. Murcia: Consejería de Educación, Formación y Empleo.

Marín, J. \& Carrillo, M. S. (1999). Test Colectivo de Eficacia Lectora (TECLE). Published manuscript. Departamento de Psicología Básica y Metodología. Universidad de Murcia. Test available at: www. pediatrasandalucia.org/Pdfs/TestEficienciaLectora.pdf [14 March 2013].

Mousty, P. \& Leybaert, J. (1999) Evaluation des habilités de lecture et d'orthographe au moyen de BELEC: données longitudinales auprès d'enfants francophones testés en 2ème et 4ème années. Revue Europé enne de Psychologie Appliquée, 49, 325-342. http://difusion.ulb.ac.be/vufind/Record/ULB-DIPOT:oai:dipot.ulb.ac. be:2013/73073/Details [20 November 2014].

Organisation for Economic Co-operation and Development (2013). PISA-Programme for International Student Assessment. Results in focus: What 15-year-olds know and what they can do with what they know. Retrieved 12 November 2014 http://www.oecd.org/pisa/keyfindings/pisa-2012-results-overview. pdf [10 March 20I4].

Piérart, B., \& Grégoire, J. (2004). Déchiffrer et coprendre: le test de closure en lecture revisité ètalonnage belge du L3 de Lobrot. Le Langage et l'Homme, 39(2), 87-100.

Pinheiro, A. M. V. (1996). Word frequency count in written Brazilian Portuguese. In S. Contento (Ed.). Psycholinguistics as multidisciplinarily connected science. Cesena: Società Editrice II Ponte Vecchio, 2, 47-52.

Pinheiro, A. M. V. (20I3). Prova de Leitura e de Escrita de palavras [Test of Reading and Writing words]. Final Technical Report approved by the Foundation for Research of the State of Minas Gerais. Process number: APQ-01914-09.

Pinheiro, A. M. V. (2015). Frequency of occurrence of words in textbooks exposed to Brazilian children in the early years of elementary school. Childes-Child Language Data Exchange System. http://childes. talkbank.org/derived [5 February 20I5].

Reybroeck, M., \& Hupet, M. (2009). Acquisition of number agreement: Effects of processing demands. Journal of Writing Research, I(2), I53-172.

Salles, J. F. d., \& Parente, M. A. d. M. P. (2002). Processos cognitivos na leitura de palavras em crianças: relações com compreensão e tempo de leitura [Cognitive processes involved in children's word reading: Relations with reading comprehension and reading time]. Psicologia: Reflexão e Crítica, 15, 321-331.

Soares, J. F. (2004). O efeito da escola no desempenho cognitivo de seus alunos. REICE-Revista Eletrónica Iberoamericana sobre Calidad, Eficacia y Cambio en Educación, 2(2), 83-I04.

Sucena, A. \& Castro, S.L. (2010). Aprender a Ler e Avaliar a Leitura. O TIL: Teste de Idade de Leitura. 2nd Edition. Coimbra: Almedina. ISBN: 978-972-40-3919-0

Sucena, A., Carneiro, J. F., \& Almeida, F. G. (2014). Assessing reading abilities of mechanical engineering college students: A prospective study. International Journal of Engineering Education, 30(2), 378-387.

Todos pela Educação (20I3). Instituto Paulo Montenegro/IBOPE, Fund. Cesgranrio, Inep. Retrieved 17 November 2014 http://www.todospelaeducacao.org.br [10 March 2014].

Vilhena, D. A., \& Pinheiro, A. M. V. (20I5). Validation and standardization of the Brazilian reading test -Sentence comprehension. Manuscript submitted for publication. 


\section{Appendix I}

\section{THE LECTURE 3 TEST OF THE ORLEC BATTERY: DISTRACTORS CLASSIFIED ACCORDING TO THEIR PROXIMITY TO THE SENTENCE, THE TARGET WORD AND THE OTHER DISTRACTORS}

I Je ferai la vaisselle demain matin, car je suis fatigué et je préfère aller au [l'll do the dishes Training tomorrow because I'm tired and l'd rather go to]

$\begin{array}{ccccc}\text { bout (end) } & \text { loup (wolf) } & \text { jour (day) } & \text { lit (bed) } & \text { loin (far) } \\ {[n T+p D]} & {[n T+p D]} & {[n T+p D]} & {[\text { Target }]} & {[n T+n D]}\end{array}$

2 Si on fait marcher trop fort sa radio, on risque de déranger les (If we turn the radio too Training loud, we risk disturbing the)

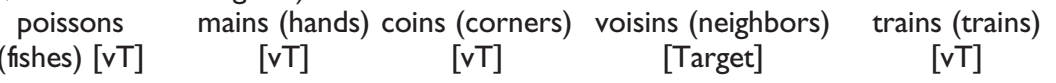

3 Mon frère a fait un voyage en Afrique et a rapporté une très originale (My brother made a Training trip to Africa and brought a very original) ville (city) statue (statue) chaleur (heat) estrade (platform) saison (season)
$[\mathrm{nT}+\mathrm{sS}]$
[Target $] \quad[\mathrm{nT}+\mathrm{sS}]$
$[\mathrm{vT}+\mathrm{sS}]$
$[\mathrm{nT}+\mathrm{sS}]$

$4 \quad$ Un homme qui conduit un véhicule s'appelle un (A man who drives a vehicle is called a)

Training

$\begin{array}{ccccc}\begin{array}{c}\text { mécanicien } \\ \text { (mechanic) }\end{array} & \begin{array}{c}\text { compagnon } \\ \text { (companion) }\end{array} & \begin{array}{c}\text { accordeur } \\ \text { (tuner) }\end{array} & \begin{array}{c}\text { conducteur } \\ \text { (driver) }\end{array} & \begin{array}{c}\text { chanteur } \\ (\text { singer })\end{array} \\ {[\mathrm{sT}+\mathrm{sS}]} & {[\mathrm{sT}]} & {[\mathrm{PT}]} & {[\text { Target }]} & {[\mathrm{PT}+\mathrm{vT}]}\end{array}$

I Test Prends le panier et va m'acheter des (Take the basket and go buy me some)

\begin{tabular}{|c|c|c|c|c|}
\hline $\begin{array}{c}\text { armoires } \\
\text { (wardrobes) } \\
{[\mathrm{nT}]}\end{array}$ & $\begin{array}{c}\text { oranges } \\
\text { (oranges) } \\
\text { [Target] }\end{array}$ & $\begin{array}{c}\text { ordures } \\
\text { (garbage) } \\
\text { [vT] }\end{array}$ & $\begin{array}{c}\text { ombres } \\
\text { (shadows) } \\
{[\mathrm{vT}]}\end{array}$ & $\begin{array}{c}\text { ordres } \\
\text { (orders) } \\
\text { [vT] }\end{array}$ \\
\hline
\end{tabular}

2 Test Si vous mangez ce gâteau, dit ma mère, vous verrez comme il est (If you eat this cake, my mother said, you will see that it is)

$\begin{array}{ccccc}\text { long (long) } & \text { rond (round) } & \text { bon (good) } & \text { doux (sweet) } & \text { chou (cabbage) } \\ {[\mathrm{PT}]} & {[\mathrm{pT}]} & {[\text { Target }]} & {[\mathrm{nT}+\mathrm{sS}]} & {[\mathrm{nT}+\mathrm{pD}]}\end{array}$

3 Test Tous les chiens ont quatre (All dogs have four)

\begin{tabular}{|c|c|c|}
\hline $\begin{array}{l}\text { bouches } \\
\text { nouths) [sS] }\end{array}$ & $\begin{array}{c}\text { pattes (paws) } \\
{[\text { Target] }}\end{array}$ & $\begin{array}{c}\text { pinces } \\
\text { (pliers) [vT] }\end{array}$ \\
\hline
\end{tabular}

4 Test J'aimerais aller sur la plage pour me baigner dans la (I would like to go to the beach for a swim in the)

\begin{tabular}{ccccc}
$\begin{array}{c}\text { guerre } \\
\text { (war) }[\mathrm{pT}]\end{array}$ & $\begin{array}{c}\text { mer (sea) } \\
{[\text { Target] }}\end{array}$ & $\begin{array}{c}\text { mère (mother) } \\
\text { [Homophone] }\end{array}$ & $\begin{array}{c}\text { marche }(\text { march) } \\
{[\mathrm{pD}]}\end{array}$ & $\begin{array}{c}\text { marque } \\
\text { (brand) }[\mathrm{pD}]\end{array}$ \\
\hline
\end{tabular}

5 Test La petite fille a mis sa (The little girl put on her) roche (rock) cloche (bell) roue (wheel) rue (street) robe (dress)

$\left[\begin{array}{lllll}\mathrm{vT}] & {[\mathrm{pD}]} & {[\mathrm{vT}]} & {[\mathrm{vD}]} & \text { [Target] }\end{array}\right.$

6 Test La gare se trouve au milieu de la (The station is in the middle of the) fille ville (city) bille (marble) boule (boule) poule (hen)
(daughter) [PT]
[Target]
$[\mathrm{pT}]$
[pD]
[pD]

7 Test II a ouvert la radio et a écouté les (He turned on the radio and listened to the) \begin{tabular}{ccccc}
$\begin{array}{c}\text { nouvelles (news) } \\
{[\text { Target] }}\end{array}$ & $\begin{array}{c}\text { chandelles } \\
\text { (candles) }[\mathrm{pT}]\end{array}$ & $\begin{array}{c}\text { voiles } \\
\text { (sails) }[\mathrm{nT}]\end{array}$ & $\begin{array}{c}\text { vitres (windows) } \\
\text { [vD] }\end{array}$ & $\begin{array}{c}\text { navires } \\
\text { (ships) [nT] }\end{array}$ \\
\hline
\end{tabular} 
8 Test II a déchiré son tablier et il s'est fait (He tore his apron and he got)

\begin{tabular}{|c|c|c|c|}
\hline $\begin{array}{l}\text { rouler } \\
\text { (rolled) } \\
{[\mathrm{nT}]}\end{array}$ & $\begin{array}{c}\text { grandir } \\
\text { (growed) } \\
\text { [vT] }\end{array}$ & $\begin{array}{l}\text { sonder } \\
\text { (sounded) } \\
{[\mathrm{pT}]}\end{array}$ & $\begin{array}{l}\text { craindre } \\
\text { (afraid) } \\
\text { [sT] }\end{array}$ \\
\hline
\end{tabular}

9 Test Un endroit où on range les livres s'appelle une (A place where we keep books is called a) pêche cuisine galerie bibliothèque porte $\begin{array}{lllll}\text { (peach) }[\mathrm{nT}] & \text { (kitchen) }[\mathrm{sS}] & \text { (gallery) }[\mathrm{sS}] & \text { (library) }[\text { Target] } & \text { (door) }[\mathrm{nT}]\end{array}$

I0 Test II y a eu un grand accident: la locomotive est sortie des (There was a big accident: the locomotive got off the)

$\begin{array}{ccccc}\begin{array}{c}\text { tiroirs } \\ \text { (drawers) }\end{array} & \begin{array}{c}\text { rails } \\ \text { (rails) }\end{array} & \begin{array}{c}\text { rayons } \\ \text { (rays) }\end{array} & \begin{array}{c}\text { routes } \\ \text { (roads) }\end{array} & \begin{array}{c}\text { rangs } \\ (\text { ranks })\end{array} \\ {[\mathrm{nT}]} & {[\text { Target] }} & {[\mathrm{vT}]} & {[\mathrm{sT}]} & {[\mathrm{vT}]}\end{array}$

II Test Ils travaillent toute la journée et le soir ils se (They work all day and at night they)

$\begin{array}{ccccc}\text { noient } & \text { brisent } & \text { sèchent } & \text { répondent } & \text { reposent } \\ (\text { drown) } & (\text { break) } & (\text { dry) } & \text { (meet) } & \text { (rest) } \\ {[\mathrm{vT}]} & {[\mathrm{vT}]} & {[\mathrm{vT}]} & {[\mathrm{vT}]} & {[\text { Target] }}\end{array}$

12 Test Vous pourriez enlever la poussière avec un (You could remove the dust with a)

$\begin{array}{ccccc}\begin{array}{c}\text { palais } \\ \text { (palace) }\end{array} & \begin{array}{c}\text { balai } \\ \text { (broom) }\end{array} & \begin{array}{c}\text { bœuf } \\ \text { (beef) }\end{array} & \begin{array}{c}\text { lard } \\ \text { (bacon) }\end{array} & \begin{array}{c}\text { four } \\ \text { (furnace) }\end{array} \\ \text { [PT] } & {[\text { Target] }} & {[\mathrm{nT}]} & {[\mathrm{nT}]} & {[\mathrm{pT}]}\end{array}$

13 Test II est parti à la chasse, c'est pourquoi il a pris son (He went out to hunt, and that is why he took his)

$\begin{array}{ccccc}\text { outil } & \text { feu } & \text { fusil (shotgun) } & \text { gentil } & \text { foin } \\ \text { (tool) }[\mathrm{sS}] & \text { (fire) }[\mathrm{nT}] & {[\text { Target }]} & \text { (gentil) }[\mathrm{vT}] & \text { (hay) }[\mathrm{nT}]\end{array}$

14 Test Mon oncle, après de longues études, est devenu (My uncle, after a long time studing, became a)

$\begin{array}{ccccc}\begin{array}{c}\text { nouille } \\ \text { (noodle) } \\ {[\mathrm{nT}]}\end{array} & \begin{array}{c}\text { médecin } \\ \text { (doctor) }\end{array} & \begin{array}{c}\text { moisi } \\ \text { (moldy) }\end{array} & \begin{array}{c}\text { monsieur } \\ (\text { sir) }\end{array} & \begin{array}{c}\text { moyen } \\ \text { (means) }\end{array} \\ {\left[\begin{array}{c}\text { [Target }] \\ {[\mathrm{nT}+\mathrm{vD}]}\end{array}\right.} & {[\mathrm{sS}+\mathrm{vD}]} & {[\mathrm{vT}]}\end{array}$

I5 Test II s'est penché sur le puits et il est tombé au (He leaned over the well and fell to the)

$\begin{array}{ccccc}\text { fond } & \text { front } & \text { frein } & \text { fard } & \text { four } \\ \text { (bottom) } & \text { (front) } & \text { (brake) } & \text { (rouge) } & \text { (furnace) } \\ {[\text { Target] }} & {[\mathrm{pT}]} & {[\mathrm{vT}]} & {[\mathrm{vT}]} & {[\mathrm{vT}]}\end{array}$

16 Test II fait chaud sur la terrasse, pourquoi ne mettez-vous pas le ...? (It's hot on the terrace, why don't you put up the)

$\begin{array}{ccccc}\begin{array}{c}\text { paravent } \\ \text { (folding screen) }\end{array} & \begin{array}{c}\text { radiateur } \\ \text { (heater) }\end{array} & \begin{array}{c}\text { parasol } \\ \text { (parasol) }\end{array} & \begin{array}{c}\text { passage } \\ \text { (passage) }\end{array} & \begin{array}{c}\text { patin } \\ \text { (roller skate) }\end{array} \\ {[\mathrm{PT}+\mathrm{sT}]} & {[\mathrm{s} \mathrm{S}+\mathrm{nT}]} & {[\mathrm{V} \text { arget] }} & {[\mathrm{vT}]} & {[\mathrm{vT}]}\end{array}$

17 Test Quand on est dans la rue, il faut faire très attention aux autos afin de ne pas se faire (When you are in the street, you have to be very careful with cars so you do not get)

$\begin{array}{ccccc}\text { laver } & \text { transporter } & \text { casser } & \text { pousser } & \text { écraser } \\ \text { (washed) } & \text { (transported) } & \text { (broken) } & \text { (pushed) } & \text { (run over) } \\ {[\mathrm{nT}+\mathrm{pT}]} & {[\mathrm{sS}+\mathrm{pT}]} & {[\mathrm{sT}+\mathrm{pT}]} & {[\mathrm{pT}]} & {[\text { Target] }}\end{array}$

I8 Test Quand vous dormirez, j'espère que vous ferez de jolis (When you sleep, I hope you will have sweet)

\begin{tabular}{|c|c|c|c|c|}
\hline $\begin{array}{c}\text { rêves } \\
\text { (dreams) } \\
\text { [Target] }\end{array}$ & $\begin{array}{c}\begin{array}{c}\text { yeux } \\
\text { (eyes) } \\
\text { [nT] }\end{array}\end{array}$ & $\begin{array}{c}\text { trous } \\
\text { (holes) } \\
\text { [nT + vD] }\end{array}$ & $\begin{array}{c}\text { rires } \\
\text { (laughters) } \\
\text { [sS] }\end{array}$ & $\begin{array}{c}\text { cous } \\
\text { (necks) } \\
{[\mathrm{nT}+\mathrm{vD}]}\end{array}$ \\
\hline
\end{tabular}


19 Test Parmi tous les jeux préférez-vous le ping-pong, le billard, les dominos, ou les ...? (Of all the games you prefer table-tennis, billiards, dominoes, or)

$\begin{array}{ccccc}\begin{array}{c}\text { douches } \\ \text { (showers) }\end{array} & \text { astres } & \text { bras } & \text { cartes } & \text { cadres } \\ {[\mathrm{vT}]} & (\mathrm{stars}) & (\mathrm{arms}) & \text { (cards) } & \text { (frames) } \\ {[\mathrm{vT}]} & {[\mathrm{nT}]} & {[\text { Target] }} & {[\mathrm{PT}]}\end{array}$

20 Test II s'est pris la main dans la porte et il s'est mis à pleurer en poussant des (He trapped his hand in the door and he started to cry and)

$\begin{array}{ccccc}\begin{array}{c}\text { bruits } \\ \text { (sounds) }\end{array} & \begin{array}{c}\text { lits } \\ \text { (beds) }\end{array} & \begin{array}{c}\text { nuits } \\ \text { (nights) }\end{array} & \begin{array}{c}\text { cris } \\ \text { (scream) }\end{array} & \begin{array}{c}\text { cas } \\ \text { (cases) }\end{array} \\ {[\mathrm{PT}+\mathrm{sS}]} & {[\mathrm{pT}]} & {[\mathrm{vD}]} & {[\text { Target] }} & {[\mathrm{vT}]}\end{array}$

2I Test Un camarade l'a poussé et il est tombé sur les (A friend pushed him over and he fell on his)

$\begin{array}{ccccc}\begin{array}{c}\text { roues } \\ \text { (wheels) }\end{array} & \begin{array}{c}\text { mains } \\ \text { (hands) }\end{array} & \begin{array}{c}\text { nains } \\ \text { (dwarfs) }\end{array} & \begin{array}{c}\text { vins } \\ \text { (wines) }\end{array} & \begin{array}{c}\text { ponts } \\ \text { (bridges) }\end{array} \\ {[\mathrm{nT}]} & {[\text { Target] }} & {[\mathrm{pT}]} & {[\mathrm{pT}]} & \text { [sS] }\end{array}$

22 Test Tout le monde est parti en voiture jusqu'à la forêt et là, nous nous sommes assis sur l'herbe, où nous avons mangé notre (Everyone went by car to the forest and there we sat on the grass, where we ate our)

$\begin{array}{ccccc}\text { rat } & \text { rang (rang) } & \text { repas (food) } & \text { quart } & \text { pas (no) } \\ (\text { rat) }[\mathrm{vT}] & {[\mathrm{vT}]} & {[\text { Target] }} & \text { (quarter) }[\mathrm{nT}] & {[\mathrm{PT}]}\end{array}$

23 Test Ils comptent aller aux courses dimanche prochain car ils aiment voir les chevaux courir sur la (They are going to the races next Sunday because they like to see the horses run on the) $\begin{array}{ccccc}\text { piste (track) } & \text { liste (list) } & \text { voûte (arch) } & \text { route (road) } & \text { mine (mine) } \\ {[\text { Target }]} & {[\mathrm{pT}]} & {[\mathrm{vT}]} & {[\mathrm{vT}+\mathrm{sS}]} & {[\mathrm{nT}]}\end{array}$

24 Test II est arrivé une drôle d'aventure à un pêcheur; il a attrapé une (A funny adventure happened to a fisherman; he caught a)

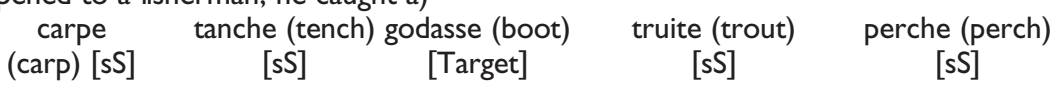

25 Test Du cratère du volcan s'échappent peu à peu des flots de (The volcano crater gradually released flows of)

$\begin{array}{ccccc}\text { vague (wave) } & \text { lave (lava) } & \text { bave (drool) } & \text { cave (cave) } & \text { rage (rage) } \\ {[\mathrm{vT}]} & {[\text { Target] }} & {[\mathrm{pT}]} & {[\mathrm{pT}]} & {[\mathrm{vT}]}\end{array}$

26 Test Pourquoi ne vous servez-vous pas d'un couteau pour manger votre ...? (Why don't you use a knife to eat your)

$\begin{array}{ccccc}\text { vin } & \text { voiture } & \text { viande } & \text { voisin } & \text { ville } \\ (\text { wine) } & \text { (car) } & \text { (meat) } & \text { (neighbor) } & \text { (city) } \\ {[\mathrm{vT}]} & {[\mathrm{vD}]} & {[\text { Target] }} & {[\mathrm{vD}]} & \text { [vT] }\end{array}$

27 Test Tous les gens sont sortis de leur maison et ont regardé les dégâts produits par l' (Everyone left their homes and watched the damage caused by the)

\begin{tabular}{ccccc} 
explosion & exposition & ascension & expédition & exagération \\
(explosion) & (exhibition) & (ascension) & (expedition) & (exaggeration) \\
[Target] & {$[\mathrm{pT}]$} & {$[\mathrm{pT}]$} & {$[\mathrm{PT}]$} & {$[\mathrm{PT}]$} \\
\hline
\end{tabular}

28 Test Nos voisins ont acheté un gros chien méchant qui doit rester devant la porte pour monter la (Our neighbors have bought a big mean dog that stays outside the door to stand) corde (rope) fuite (escape) chaîne (chain) grade (grade) garde (guard)
[vT]
[nT]
[vS]
$[\mathrm{pT}]$
[Target]

29 Test C'est l'hiver, et cette nuit sont tombés de gros (It's winter, and that night fell large)

$\begin{array}{ccccc}\text { flacons } & \text { cocons } & \text { flocons } & \text { sapins } & \text { sabots } \\ \text { (bottles) } & \text { (cocoons) } & \text { (flakes) } & \text { (firs) } & \text { (shoes) } \\ {[\mathrm{pT}]} & {[\mathrm{PT}]} & {[\text { Target] }} & {[\mathrm{sS}]} & {[\mathrm{sS}]}\end{array}$

(Continues) 
30 Test Nous sommes allés nous promener dans la forêt et nous avons rapporté des (We went for a walk in the forest and we collected some)

$\begin{array}{ccccc}\begin{array}{c}\text { chalets } \\ \text { (cottages) }\end{array} & \begin{array}{c}\text { champignons } \\ \text { (mushrooms) }\end{array} & \begin{array}{c}\text { châtaigniers } \\ \text { chestnut trees) }\end{array} & \begin{array}{c}\text { châteaux } \\ \text { (castles) }\end{array} & \begin{array}{c}\text { chapeaux } \\ \text { (hats) }\end{array} \\ {[\mathrm{pT}]} & {[\text { Target] }} & {[\text { Target }+\mathrm{vT}]} & {[\mathrm{pT}+\mathrm{vD}]} & {[\mathrm{pT}+\mathrm{vD}]}\end{array}$

3I Test C'est le printemps, les bois sont fleuris de (It's spring, the woods are flowered with)

$\begin{array}{ccccc}\begin{array}{c}\text { quilles } \\ \text { (bowling) }\end{array} & \begin{array}{c}\text { jongleurs } \\ \text { (jugglers) }\end{array} & \begin{array}{c}\text { jonques } \\ \text { (junks) }\end{array} & \begin{array}{c}\text { jonquilles } \\ \text { (daffodils) }\end{array} & \begin{array}{c}\text { feuilles } \\ \text { (leaves) }\end{array} \\ {[\mathrm{PT}]} & {[\mathrm{PT}+\mathrm{vT}]} & {[\mathrm{pT}]} & {[\text { Target] }} & {[\mathrm{sT}+\mathrm{vT}+\mathrm{sS}]}\end{array}$

32 Test La fatigue, le surmenage, ont rendu cette personne (The fatigue, the overwork, made this person)

\begin{tabular}{|c|c|c|c|c|}
\hline $\begin{array}{c}\text { alerte } \\
\text { (alert) [sS] }\end{array}$ & $\begin{array}{c}\text { petite } \\
\text { (small) }[\mathrm{sS}]\end{array}$ & $\begin{array}{c}\text { aimable } \\
\text { (friendly) [sS] }\end{array}$ & $\begin{array}{c}\text { maligne } \\
\text { (malignant) }[\mathrm{sS}]\end{array}$ & $\begin{array}{c}\text { souffrante } \\
\text { (suffer) [Target] }\end{array}$ \\
\hline
\end{tabular}

33 Test Le prestidigitateur, en plantant un couteau dans la paume de sa main, nous a (The magician, by sticking a knife into the palm of his hand, made us)

$\begin{array}{ccccc}\text { payés } & \text { effacés } & \text { fouillés } & \text { effrayés } & \text { ensanglantés } \\ (\text { paid }) & \text { (cleared) } & \text { (searched) } & \text { (scared) } & \text { (bloody) } \\ {[\mathrm{pT}]} & {[\mathrm{pT}]} & {[\mathrm{pT}]} & {[\text { Target] }} & {[\mathrm{sS}+\mathrm{pT}]}\end{array}$

34 Test Les hommes aiment ce qui est nouveau parce que cela satisfait leur (Men love what is new because it satisfies their)

$\begin{array}{ccccc}\begin{array}{c}\text { bonté } \\ \text { (goodness) }\end{array} & \begin{array}{c}\text { amitié } \\ \text { (friendship) }\end{array} & \begin{array}{c}\text { curiosité } \\ \text { (curiosity) }\end{array} & \begin{array}{c}\text { vanité } \\ \text { (vanity) }\end{array} & \begin{array}{c}\text { justice } \\ \text { (justice) }\end{array} \\ {[\mathrm{sS}+\mathrm{pT}]} & {[\mathrm{sS}+\mathrm{pT}]} & {[\text { Target] }} & {[\mathrm{sS}+\mathrm{pT}]} & {[\mathrm{sS}]}\end{array}$

35 Test Le mari d'une fille est pour la mère de cette fille un (The husband of a daughter is to the mother of that girl a)

\begin{tabular}{|c|c|c|c|c|}
\hline $\begin{array}{l}\text { géant } \\
\text { (giant) } \\
{[\mathrm{PT}]}\end{array}$ & $\begin{array}{c}\text { agent } \\
\text { (agent) } \\
{[\mathrm{PT}]}\end{array}$ & $\begin{array}{c}\text { gendre } \\
\text { (son in law) } \\
\text { [Target] }\end{array}$ & $\begin{array}{c}\text { geôlier } \\
\text { (jailer) } \\
\text { [vT] }\end{array}$ & $\begin{array}{c}\text { gendarme } \\
\text { (policeman) } \\
{[\mathrm{PT}]}\end{array}$ \\
\hline
\end{tabular}

36 Test Les réfrigérateurs empêchent la nourriture de (Refrigerators prevent food from)

$\begin{array}{ccccc}\begin{array}{c}\text { mourir } \\ \text { (dying) }\end{array} & \begin{array}{c}\text { rouiller } \\ \text { (rusting) }\end{array} & \begin{array}{c}\text { se souiller } \\ \text { (being defiled) }\end{array} & \begin{array}{c}\text { geler } \\ \text { (freezing) }\end{array} & \begin{array}{c}\text { pourrir } \\ \text { (rotting) }\end{array} \\ {[\mathrm{sS}+\mathrm{vT}]} & {[\mathrm{sS}+\mathrm{vT}]} & {[\mathrm{vT}]} & {[\mathrm{sS}]} & {[\text { Target] }}\end{array}$

Target: correct alternative; pT: phonological proximity to the Target; pD: phonological proximity to the Distractors; vS: visual proximity to the Sentence; vT: visual proximity to the Target; vD: visual proximity to the Distractors; sS: semantic proximity to the Sentence; sT: semantic proximity to the Target; $\mathrm{nT}$ : no proximity to the Target; $\mathrm{nD}$ : no proximity to the Distractors. 